MedieKultur | Journal of media and communication research | ISSN 1901-9726

Article - Open section

\title{
Communication ethics and the receiver Contribution to an ethic of strategic mass communication
}

\author{
Jan Foght Mikkelsen
}

MedieKultur 2017, 63, 85-102

Published by SMID | Society of Media researchers In Denmark | www.smid.dk The online version of this text can be found open access at https://tidsskrift.dk/mediekultur

\begin{abstract}
The author wants to contribute to an ethic of strategic communication by proposing a general ethical norm for all strategic communication. The author wants to outline the focal point of the norm, the ethical basis of the norm, a precise definition of the norm and to show how it works. This norm focuses exclusively on the persuasive means used to get the sender's message across. The question is whether the rhetorical means mislead the receiver. In order to answer this question, a norm of "fairness", defined from the viewpoint of the receiver, is proposed. It is shown how "fairness" allows us to identify misleading means and to evaluate them on a common ethical ground.
\end{abstract}

The purpose of this article is to contribute to an ethic of strategic communication (cf. Windahl \& Signitzer, 1995; Jowett \& O'Donnell, 2008) by proposing the ethical norm of "fairness" as a general norm applying to the different types of strategic communication, to outline the focal point of the norm and the ethical basis of the norm, and to show how it works in an ethical evaluation.

My contribution to an ethic of strategic communication focuses on the relationship between sender and receiver and especially on the persuasive means used to get the sender's message across. It examines the relationship between purpose and means, but a stance on the message itself is not taken. The question is whether the persuasive 
means are ethically acceptable from the receiver's point of view: Are they unfair, and do they mislead the receiver? What is unfairness and fairness in the context of strategic communication? And how can these terms be defined and operationalized when there is no absolute ethical key? When are persuasive means misleading, and how can such misleading communication be identified?

A powerful sender's use of professional communication planning and the deliberate use of persuasive means always represent an exertion of communicative power (cf. L'Etang, 2011). So, senders have an ethical responsibility for the way they exercise this power to reach their goal (cf. Foucault, 1994). In theories of strategic communication and especially in practice, there has been a strong preoccupation with the way senders could get their messages through to the receiver and reach their goals. That is to say, how effectiveness will increase by making the rhetorical means more persuasive (cf. Botan 1997; Rice \& Atkin, 2001; Windahl \& Signitzer, 1992; Johannesen et al., 2008). This may result in an ethical problem, namely, the manipulation of the receiver. So, Guttman and Thompson say in their review of "Ethics in Health Communication" that ethical obligations regarding reliability and accuracy may conflict with the obligation of health promotors to maximize the effectiveness of their messages:

It is not uncommon for health promotors to argue that their ethical obligation is to employ claims that are as persuasive as possible, regardless of their accuracy. It is common to find appeals in public health communication campaigns that exaggerate [...] the magnitude of the problem or the potential negative consequences of not adopting the recommended practices (Guttman \& Thompson, 2011, p. 300).

To a lesser extent, the discussion of strategic communication has been concerned with which means of persuasion are ethically acceptable to use in order to achieve the purpose. An exception to this is the extensive research in PR communication (cf. Merkelsen, 2010). However, as one critical PR researcher L'Etang points out, "there are enormous tensions between the ideals of public relations [...] and the fact that this occupation is not public sector organizations but are outgrowths of power" (L'Etang, 2011, p. 233).

Ethics in strategic communication is about showing respect for the receiver's right to self-determination, which, therefore, requires a certain degree of self-restriction on the part of the sender. If communication planning only identifies with the sender by exclusively considering his or her demands for effectiveness, there will be a risk of letting the ends justify the means (cf. Botan, 1997, p. 196; Guttman \& Thompson, 2011).

So, my contribution to an ethic of strategic communication isolates one single problem - the way the sender treats the receiver - and examines it regardless of type of media and communication, that is, as a crossover problem in the media and communication profession. There are, of course, other ethical problems connected with the various types of strategic communication or types of communication profession 
(cf. Gordon \& Kittross, 1999; Cheney et al., 2011; Drumwright, 2013). And, usually, communication ethics theories deal with ethical problems related to only one specific profession but not with ethical problems across different communication professions.

In contrast to ordinary communication, strategic communication always attempts to reach a certain goal by using professional communication planning and deliberate means of persuasion (cf. Botan, 1997; Windahl \& Signitzer, 1992, pp. 1, 101). Strategic communication is normally persuasive in the end. Even information campaigns are almost always directed at influencing the conduct of the target group. Thus, information campaigns, which are apparently meant to inform the citizens neutrally about the role of the parliament in the European Union in connection with election of politicians to the parliament, want to optimize the number of citizens who vote in order to legitimize the parliament (cf. Septrup \& Fruensgaard, 2010, p. 205).

Typical examples of strategic communication are health campaigns and other forms of public communication campaigns, political communication and public relations. They all have a goal and want to influence the receivers in some way. Windahl and Signitzer give a definition of "campaign" that may be considered as a prototypical example of strategic mass communication:

Communication campaigns are purposive attempts to inform, persuade, or motivate behavior changes in a relatively well-defined and large audience [...] typically within a given time period, by means of organized communication activities involving mass media and often complemented by interpersonal support (1995, p. 101).

My contribution to an ethic of strategic communication draws its inspiration from the German philosopher Jürgen Habermas' formal discourse ethics (Habermas, 1991, 1993) and especially from the tradition of existentialist philosophy called 'dialogical ethics' (Buber, 1965; Levinas, 1991; Ricoeur, 1992). This ethic also draws its inspiration from postmodern, hermeneutical and neopragmatic philosophers (Rorty, 1989; Vattimo, 2004). Communication ethics are, of course, primarily based on fundamental ethical values such as responsibility, equality of dignity and the right to self-determination (cf. Norman, 1994; Vattimo, 2004). It only makes sense to speak about ethics in strategic communication if these central values are accepted. If they are not, misleading and deceiving the receiver become legitimate, for instance, because manipulation "serves a good purpose", or because the message is "for the best of the receiver" (in the sender's opinion, that is!).

In the following, I shall focus exclusively on this ethical problem, which I consider the main ethical problem in strategic communication. I shall outline the focal point of this communication ethic and state the case for the proposed norm of "fairness" and discuss what fair and unfair communication is and also how to operationalize the norm in an ethical evaluation. In addition, I shall consider the relationship between the exercise of power and ethical responsibility. 


\section{The focal point of the ethical norm}

From the perspective of an ethic of strategic communication, it is important to distinguish between the message to be communicated and the way it is communicated, that is, the way the sender attempts to persuade the receiver to accept some message or claim. If you like, the message can be judged by various religious, political, and moral criteria as to whether it is desirable to expose the receiver to such an influence. Ethics in strategic communication, on the other hand, does not take a stance on the question of whether the message is morally improving, ideologically or politically correct, etc. Such a substantial judgement must be separated from a more formal judgement of the way a given rhetorical influence is exerted, that is to say, of the means of persuasion being applied (cf. Johannesen et al., 2008, p.101). The same message can be communicated in different ways, and there can be different arguments or data for the same claim (cf. Toulmin, 1974) of which some will be misleading and others not.

In a (post)modern society characterized by a pluralism of values, one cannot establish absolute and valid norms for what is a "good" message. On this, there is seldom consensus but primarily a plurality of mutually conflicting political and ethical judgements of what is good (cf. the diagnosis in Rorty, 1989, Vattimo, 2004). It is, therefore, hardly realistic to imagine that consensus can be achieved on what a "good" message is (except, perhaps, when it is about banalities). There are very few indisputable claims or messages. That is why a general communication ethic cannot be related to the message of the communication and its ethical value. It would make ethics dependent upon, for instance, particular political or religious interests or a specific view of "the good life". This is also in line with Habermas' formal discourse ethics (cf. Habermas, 1991, 1993).

\section{The ethical basis of the ethical norm}

In line with the French philosopher Emmanuel Levinas (1991), Dennis Mumby states that "the study of ethics is centrally concerned with the ways in which one engages with 'the other'; to what extent the other is treated as an object to be strategically manipulated or as a human [...]" (Mumby, 2011, p. 94). "The other" is, in this context, the receiver. So, the receiver ought to be respected as a self-determining subject of equal dignity. To mislead, one's receiver is to deprive the receiver of the possibility of judging and of making his or her own choice whether to consent to the message. By definition, manipulation makes the receiver an object of communication, a target to be hit. Manipulation always demonstrates lack of respect for the person addressed - independent of a possibly "good" intention. It is a reification of the receiver to make him or her a tool of the sender's own aims. So, manipulation of any kind has ethically undesirable consequences for the receiver, and manipulation is in conflict with fundamental ethical values of our culture and its humanistic view of man. In our Western culture, people are seen as having certain ethical 
rights and qualities: human dignity, self-determination, responsibility, and vulnerability (cf. Vatimo, 2004; Rorty, 1989; Norman, 2004).

An ethical judgement demands a criterion or norm according to which one can judge the ethical status of the ways and means of communication. Such a norm must be: 1) formal, that is so say, leave out an account of the message of the communication, 2) formulated on a very general level, and 3) based on fundamental ethical values such as respect of the receiver's right of self-determination and dignity (cf. Brurås, 2002).

Against this background, one can direct the following ethical rule to the sender: Communicate to your receiver as if it were to yourself, a subject having the same rights and claims of respect and not to an object that can be treated as an instrument. That means in a way in which the sender himself would like to be treated if he were in the receiver's situation (cf. "the Golden Rule" according to which reciprocity is a central ethical principle; cf. Ricoeur, 1992, p. 225 and Kant's categorical imperative). The sender ought to put himself in the receiver's place when choosing the means of communication and reflect upon its consequences for the receiver.

\section{The norm of the communication ethic}

The sender has an obligation to respect the right and possibility of the self-determination of the receiver and, therefore, to communicate in a way that is not misleading, i.e., in a fair way. So, "fairness" is the central norm, but what does this mean in the context of strategic mass communication? First of all, it must be said that "fairness" is not a clear-cut term in English. But, unfortunately, there is no English term for the old Danish word "redelighed" or the German "Redlichkeit". The Danish "redelighed" is used about a way of acting that is without deception; the concept comprises how you treat and relate to another person when you are acting or communicating (cf. Jørgensen \& Onsberg, 1999). Consequently, the Danish word covers more than the English words fairness, honesty or integrity (cf. Jørgensen, 2007). Anyway, I have chosen to use the word "fairness", and I shall specify its meaning in this context of communication ethics.

The norm of fairness has been proposed as a central norm in communication ethics by many others (cf. Gordon \& Kittross, 1999; Merkelsen, 2010; Botan, 1997). Most often, fairness occurs in journalism ethics, especially in connection with news reporting. The norm is defined in many different ways, for example, as intended objectivity, neutrality, impartiality and balance (cf. Jønch-Clausen \& Lyngbye, 2007). However, fairness is usually not precisely defined because its meaning is taken for granted. In the following, I shall look closer at a few of these definitions in order to examine their relevance in relation to an ethic for strategic mass communication.

The Ethical Journalism Network defines fairness together with impartiality: 
Most stories have at least two sides. While there is no obligation to present every side in every piece, stories should be told balanced and add context. Objectivity is not always possible [...], but impartial reporting builds on trust and confidence (ethical journalism network.org/who we are/ 5-principles-of-journalism).

This definition focuses on fairness as balanced and impartial reporting and requires the journalist to add context to the "raw" news or facts. But the definition seems to be vague and imprecise and, therefore, also very difficult to operationalize. How much context and which context should be added? This decision relies on a judgement, but the Ethical Journalism Network gives no guidelines for such a judgement.

In R. E. Hanson's Mass Communication (2017, 3rd. ed.), fairness is combined with truthfulness:

Journalists need to make a commitment to telling the truth. This includes not giving false or made-up reports, and telling truthful stories that are not intended to deceive the audience. This may require reporters to provide not only the facts but also the context surrounding them (Hanson, 2017, p. 250).

The point of not deceiving the audience is relevant to strategic and persuasive communication. But the definition is insufficient because, as we shall see, telling the truth is no guarantee that the receiver is not deceived. And, again, one may ask how much information and context must the reporter provide?

There are some problems with the definitions of fairness given by journalism ethics: The norm is defined too vaguely and imprecisely, which makes it hard to operationalize in a concrete judgement of the ethical status of the persuasive means used in strategic communication. Moreover, the journalistic norm of fairness includes many concepts that are not relevant in relation to the ways in which strategic communication tries to persuade the receiver such as impartiality, balance, neutrality and intended objectivity, norms that allow all sides of an issue to be voiced in the public forum (cf. Christians, 2015). However, such norms cannot be used to judge the way a campaign tries to get the receiver's approval for some claim. Furthermore, this article does not deal with an ethical judgement of the methods of communication and persuasion in news or other forms of journalism. This is because news is not persuasive or goal-oriented in the same way as health campaigns and other types of strategic communication are. And, normally, there are no sides or parties speaking in persuasive communication except for the sender himself or herself, who is the only "party" speaking.

The examined definitions of fairness do not have much relevance to an ethic of strategic communication. An exception is the definition given by J. M. Kittross in Gordon $\&$ Kittross (1999). In opposition to most other definitions, Kittross places the receiver in a central position, namely, as the one who must reach his or her own conclusions - just as in strategic communication. According to Kittross, the journalist must give the receiver enough information for judgements or decisions to be made validly: "Of 
particular importance is the need to provide sufficient valid and reliable information that will allow receivers to reach their own conclusions" (Gordon \& Kittross, 1999, p. 86). Kittross's definition is relevant to an ethic of strategic communication, but it is difficult to operationalize. How should a sender decide when there is sufficient information to allow receivers to reach their own conclusions on a fair basis? This question is not possible to answer without some kind of intersubjective guidelines. But Kittross gives no guidelines. And this is a serious problem with which a useful definition of fairness has to deal (see the section "When is communication misleading?" in this article).

I shall try to give the norm a precise and specific meaning and to define fairness in a way that makes it possible to operationalize the norm in the context of an ethic for strategic communication. This must include giving some useful guidelines for making an ethical judgement of the means used to persuade the receiver. And it must entail that the concept be narrowed to the ways persuasion is used in strategic communication. In journalism ethics, the concept of fairness means and includes too much and is imprecisely defined. This is the conclusion of a comprehensive and thorough investigation of the different definitions of fairness given in journalism ethics (Jønch-Clausen \& Lungbye, 2007).

The problems with the definitions of fairness given in journalism ethics are partly caused by the fact that the concept of "fairness" belongs to the category of so-called exclusion concepts. Such concepts can only be defined negatively: that is, as a method of persuasion that is not unfair. Fairness, therefore, is the absence of unfairness. And, as we shall see, only a negative definition of an exclusion concept allows a precise definition that allows the operationalization of the concept (see next section).

\section{Fairness and unfairness}

The logical conception of fairness makes the best sense when applied to a person's attitude to others when communicating. A sender, therefore, can act unfairly towards a receiver (namely, by deceiving him) but not by communicating a message that is unfair. Thus, a true message can very well be communicated in an unfair way (cf. Johannesen et al., 2008, p. 101). The norm of fairness, briefly, is about the fact that a sender should not mislead the receiver - no matter what the message is.

As we shall see, unfairness is something else and something more than the sender's truthfulness and honesty. The two qualities are subsets of the norm of fairness: they are both necessary but not sufficient conditions for fair communication. It is, of course, not possible deliberately to speak untruly and, at the same time, to be fair. Nor can one be dishonest or unreliable and, at the same time, be fair. A sender, of course, deceives the receiver when he only pretends to mean what he says. On the other hand, to put forward a true claim does not necessarily imply that the rhetorical means being used to persuade 
the receiver are fair - although this is a widespread misunderstanding (cf. Johannesen et al., 2008, p.101).

An example of this is a campaign from August 2002 by the environmental organisation Greenpeace. Greenpeace calls attention to the fact that the greenhouse effect is due to warming and climate change. For instance, anthropogenic heating makes the glaciers melt, and this claim is supported and illustrated with pictures of the same glacier at Svalbard in Norway from 1928 and 2002, respectively. The tremendous melting is obvious with no room for doubt, and something similar holds good for many other glaciers. Unfortunately, for Greenpeace, some geological experts knew that the glaciers represented had melted because of an unusually warm period in the late 1920s. So, a misleading argument or evidence (i.e., the photo) is presented to the receiver in order to persuade him to believe that the glaciers are melting because of the greenhouse effect. However, the photo has no connection to this effect at all. Nothing (probably) is wrong with the claim, but the concrete argumentation for it misleads the receiver. This method of argumentation is not only unethical but also dangerous for the sender - when discovered. Misleading the receiver threatens both the credibility and the image of the sender.

So, the method of persuasion does not automatically follow from the claim itself; there will always be different ways of communicating it. A sender could always have chosen otherwise: a different angle, different arguments, different points-of-view and sources, a different composition, different aesthetic and rhetorical means, etc. That is the sender's rhetorical choice. And when one has a choice, one also always has a responsibility.

Ideally, a message should always be put at stake between sender and receiver. In that case, the receiver himself can be responsible for his approval. The central ethical problem is whether the receiver is addressed as a self-determining subject. Thus, the norm of fairness is connected with a certain humanistic view of man - not with a claim for a certain scientific, political, or religious truth (cf. Rorty, 1989, 1999, p. 72; Vattimo, 2004; Norman, 2004).

The question of fairness is concerned with the sender, whether he respects the selfdetermination of the receiver or tries to persuade the receiver by misleading him or her. That happens if the receiver's approval of a claim depends on whether he is unable to see through a misleading argumentation in a specific situation. In that case, the receiver is misled to accept something he normally would not accept; and, in this way, the receiver's possibility for self-determination is suspended. So, in principle, the norm of fairness is relevant to persuasive communication (cf. Jørgensen \& Onsberg, 1999). 


\section{Typical methods of unfair communication}

Fairness belongs to the category of so-called exclusion concepts or "excluders" such as "objective" and "genuine" (cf. Hall, 1959). Such concepts cannot be defined positively but only negatively: that is, as everything that is not unfair, etc. Fairness, therefore, is absence of unfairness. But then, what is "unfairness"? It is all those arguments and rhetorical means that mislead the receiver. Unfair is any argumentation that, in the concrete communication situation, (probably) misleads the receiver and, at the same time, makes intransparent the basis on which the receiver is invited to give his approval to the claim. In the situation, therefore, the receiver has no possibility of seeing through the unreasonable basis on which he is invited to give his approval. And if he had been aware of it, he would hardly have given it.

In practice, both fair and unfair argumentation can appear in infinitely many ways. It is, therefore, extremely difficult to say something concrete and precise about what fair strategic communication looks like. The general demand for fairness is difficult to make more specific in the positive sense of giving practical rules of thumb for good strategic communication. Fairness can solely be defined as everything that is not unfair. Because of its status as an exclusion concept, fairness must be defined negatively, that is, via typical ways of being unfair such as:

1. Deliberate lies and untruths in which the sender believes himself

2. Deliberate or accidental suppression and omission of information highly relevant to the receiver in relation to the message

3. Deliberate or accidental distortion by simplification, exaggeration or understatements with probable misleading effect

4. Suggestive rhetoric to stimulate the receiver intuitively to draw unreasonable conclusions.

In a similar way, Jørgensen and Onsberg (1999, p. 97) operate with three categories of unfair argumentation, namely, persuasion by means of lying, suppression and distortion. But, according to Jørgensen and Onsberg, only misleading the receiver deliberately is seen as unfair. This because "you can only be accused of unfairness if you act in bad faith." (Jørgensen, 2007, p.172). So the question of unfairness is closely connected to a sender's (bad) intention. Paradoxically, Jørgensen and Onsberg admit that it is impossible to know or prove whether a sender had the intention to mislead or not (Jørgensen \& Onsberg, 1999, p. 99).

I do not think this is a tenable position because 1) a sender can communicate in an unfair way without the intention to do so. You might call this "disinformation" in contrast to deliberate "misinformation". The sender can be ethically blind and, for example, exaggerate or omit information important to the receiver because of pure thoughtlessness (cf. Johannesen et al., 2008, p.166 and, later, in this article). Or it may be 
because strategic communication has a heavy focus on the efficiency of the rhetorical means used to persuade the receiver. Therefore, the sender does not follow the Golden Rule and does not put himself in the place of the receiver. 2) It is not the sender's intention that has an effect on the receiver but the actual method through which a media product is communicated. It does not matter from the point of view of the receiver whether a misleading method of persuasion is used deliberately or unintentionally. But, of course, a deliberate intention makes it worse. So, a communication product is considered to be unfair if the probable effect on the receiver is misleading.

I have adopted the three categories of unfair argumentation from Jørgensen and Onsberg but reformulated them in a way that makes the categories or methods of unfair argumentation independent of the sender's conscious bad intention. This is because my focus is on the method of persuasion and its probable effect on the receiver, which is in accordance with a consequentialist ethical point-of-view (cf. Mikkelsen, 2007).

I have added a fourth category of unfair argumentation: Suggestive rhetoric that stimulates the receiver intuitively to draw unreasonable conclusions. An example of unacceptably suggestive rhetoric was seen in 1999 when NATO bombed Kosovo and Serbia by means of fighter-bombers. These attacks were called "an air campaign", "a humanitarian action" and a "non-war". By using such suggestive rhetoric, the politicians and the populations in the NATO member countries were supposed to see themselves as not part of a lethal war with the risk they might protest against it. This suggestive rhetoric compares to "framing" (cf. Lakoff, 2004, 2008) - more precisely, emotional or associative framing, which is also deceptive. An associative way of framing appeals to the receiver's "fast and unconscious thinking" (Lakoff, 2008, p. 223). This is called the "reflexive system" as opposed to the conscious and rational "reflective system" (Kahneman, 2011).

George Lakoff gives two different examples of suggestive framing: Calling a tax cut a "tax relief", as a conservative would, is an emotional suggestion but not deceptive. However, says Lakoff:

\footnotetext{
Frames can also be used manipulatively. The use, for example, of the expression 'Clear Skies Act' to name an act that increases air pollution is a manipulative frame. And it's used to cover up a weakness that conservatives have, namely that the public doesn't like legislation that increases air pollution, and so they give it a name that conveys the opposite frame. That is pure manipulation (Lakoff, 2004, p.100).
}

The misleading part lies typically in what is not said directly but in what a receiver will intuitively conclude from what is said. The misdirection lies in what the media product communicates in an implicit way by using significant omissions, suggestive combinations of information, suggestive choice of words, gaps, etc., which is to say, implicit rhetorical guidance of the receiver's thinking and interpretation. A misleading rhetoric appeals to unconscious thinking (cf. Lakoff, 2008) or to what the cognitive scientist Daniel Kahnemann calls "fast thinking" as opposed to slow and conscious thinking. According 
to Kahneman, the system of fast and intuitive thinking is more easily fooled and deceived (cf. Kahneman, 2011). Nobody of sound mind would approve of an argument built on untruths, omission of relevant information, distortions and suggestions. That is, if the person is conscious of such an unreasonable basis of argumentation. But that is doubtful if the method of argumentation is intransparent or if the receiver has faulty previous knowledge or lacks alternative information. In that case, it is unlikely that the receiver will notice untruths, distortions, omissions of relevant information, etc.

\section{When is communication misleading?}

When is a sender's use of one or more of the typical methods of misleading argumentation actually misleading? In other words, when does the use of these ways of communicating have a probable misleading effect on the receiver? How can the ethical norm of fairness be operationalized in a concrete evaluation? In the following, I shall try to answer these questions.

Misdirection mostly appears in the form of an omission of relevant information, simplification and suggestions of different kinds. But are all omissions, simplifications, etc., misleading? No! For example, it is inevitable that a sender must omit a lot of information, possible sources, or viewpoints and simplify problems for the sake of brevity and creating an angle. In terms of unfairness, the question is not whether information, etc., has been omitted, but what has been omitted and whether that is reasonable and fair from the receiver's point-of-view.

Unfortunately, the norm for fairness cannot be operationalized in a simple way. What is unfair is relative - in relation to the context of the argument, the rules of the genre, and the whole communication situation. What is misleading in a given media product cannot be decided by focussing on isolated text elements. For instance, the use of dramatic reconstruction or a musical score in a documentary, the editing of a scene, or the use of passives or metaphors, etc., as is often the case. There is no ethical key for fairness in strategic communication that a sender can consult, no objective rules that can be followed mechanically. As in other ethical cases, it is a matter of judgement that is always disputable. This judgement, of course, must be qualified and non-subjective. It, therefore, requires ethical competence (cf. Vetlesen, 2007).

Whether something is misleading depends on the total context of argumentation in which, for instance, a simplification is included and on the communication situation of which a media product is a part. To investigate the possible unfairness of a media product, one must answer the following questions, all related to the total communication situation:

1. What are the media competence and the interpretation competence of the target group? What relevant questions are they able to ask, and how great is their 
previous knowledge in relation to the subject? Age and education play a central role here.

2. What are the purpose, image, ethos and legal status of the sender organisation: Is it private or public, and what interests does it take care of?

3. What is the purpose of and what are the rules of the genre? Each genre has its own legitimate rhetoric. These rules decide what a receiver, within reason, can expect in terms of research and documentation of claims, the extent of pedagogical simplification and humorous exaggeration, explicit subjectivity, etc. (cf. Mikkelsen, 2002).

It is a widespread belief that non-rational and non-objective argumentation, including the use of metaphors, aesthetic or fictional devices, is misleading per se especially because this rhetoric is intransparent and emotionally appealing (cf. Ward, 2005, on documentary film; Johannesen et al., 2008, p. 108). But rational appeal (logos) can only mislead because data based on solely rationality can be untrue, omit relevant information, distort by simplification or lead the receiver to make unreasonable inferences.

Texts that appeal to feelings and a sense of humour can be difficult to see through, but such texts are not for that reason misleading and so not unfair. It follows logically from the definition of fairness that intransparent argumentation is only unfair if it is misleading at the same time.

Discussing ethical problems in communication turns out to be much more difficult in practice than one would imagine at first. In fact, there are no objective criteria for unfairness that can be coined as rules of thumb. The very fact that it is so complicated requires ethical competence from both communication planners and media researchers whose job it is to educate these planners. The good will not to manipulate is not enough to ensure fair communication (unfortunately). The sender should also be able to put himself in the receiver's place and, in a qualified way, judge the chosen means of persuasion and their ethical consequences for the receiver.

\section{Power and ethical responsibility}

Senders of planned mass communication are often financially, politically, or administratively powerful organisations with great media influence (cf. L'Etang, 2011, p. 231). They have the capacity to make a difference: They can afford campaigns; they want to communicate with receivers; they set the agenda; they define "truths" and ways of presenting problems; and they suggest solutions. In this respect, the receiver is normally the weaker party. The relationship between sender and receiver in mass communication is asymmetrical with respect to power, knowledge, and the possibility of communication. The communication is one-way and not invited. The receiver has no possibility of asking the sender, for instance, about comprehensiveness, truth, omissions, or relevance. But, 
of course, there is a possibility for feedback in digital communication and in the social media. However, these kinds of communication are not in focus here.

Because of the asymmetry, the receiver ought to be protected from manipulative methods of communication, and the more asymmetrical the relationship between sender and receiver is, the more there is a need for an ethic of strategic communication because of the increasing possibility that the sender misuses his dominant position to manipulate the receiver (cf. Jørgensen \& Onsberg, 1999, p. 97).

Strategic communication is, inevitably, always the exercising of communicative power over the receiver. According to Michel Foucault, power is "games of strategy", that is "strategies by which individuals try to direct and control the conduct of others" (Foucault, 1994, p. 298). The sender is trying to influence, direct and control the conduct or attitude of the receiver, that is, to control or influence the receiver's field of possibilities. And, in this context, the ethical concern should be about playing "the games of power with as little domination as possible" (ibid.) and managing the space of power in the relationship in a non-authoritarian manner. In terms of the ethics of planned mass communication, that means to communicate with the receiver in a non-manipulative or fair way.

\section{Communication planning and ethical blindness}

The relationship between sender and receiver is asymmetrical, but the sender also addresses a remote and faceless "target group" to which he has no personal relationship. The sender, therefore, has no need to see his receiver face-to-face, to bear the ethical appeal coming from the other's glance and face (cf. Levinas, 1991). Seen from the point of view of a sender of mass communication, the receiver is not a person or human being but a "target group", a target to be hit. The face of the receiver, with its ethical appeal, is, so to speak, effaced at the moment the receiver, as a moral human being, is transformed into a member of the sender's target group. And a target group is just a sample of significant traits relevant from the sender's point of view. In this transformation, the target group is depersonalized and dehumanized and thereby made ethically vulnerable because they are objectified (cf. Bauman, 1993, p. 127).

The segmentation of the target group, especially when quantitative research methods are used, is a rational procedure and part of the communicative planning. It is also vital for attaining the sender's communicative goal. At the same time, such planning makes the sender ethically blind: This is because the planning implies the effacing of the receiver's face and the dehumanizing reduction of concrete individuals to significant traits. Not only is the "target group" remote and "faceless", it becomes almost a non-human "object". It, therefore, becomes easier to disregard ethical considerations and to avoid acting in an ethically responsive way with the receivers. The asymmetrical relation of power and the distance between sender and the target group pave the way for an abuse of power. Both the Polish sociologist Zygmunt Bauman and the Norwegian philosopher Arne 
Johan Vetlesen point out that distance has a huge impact on the ethical relationship between people - distance is a mechanism that creates immorality (Bauman, 1993, p. 145; Vetlesen, 2007, p. 163).

In this way, a sender is almost inevitably made ethically blind by the professional communicative planning and the rhetorical effort being made to communicate as efficiently as possible. A sender is interested, first of all, in achieving his goal (that is why he uses planning) and not in the communicatively fair treatment of his receiver. And the more there is at stake for the sender - profit, political gain, prestige, etc. - the bigger the temptation is to use misleading rhetorical means to achieve his or her goal. Intuitively, it seems legitimate to use manipulative means if the purpose is good; and, normally, senders are convinced that they have a morally or politically good and important purpose (cf. Guttman \& Thompson, 2011, p. 300). But so do all senders with their conflicting and contradictory messages. So, by pure thoughtlessness, it is possible for a sender with no evil intentions to mislead the receiver (cf. Johannesen et al., 2008, p. 166). To communicate in an unfair and misleading way does not at all require a bad and manipulative intention. The criterion of unfairness is not the existence of a misleading intention; but, of course, such a deliberate intention makes misleading worse.

Ethical blindness is, so to speak, built into the position or role of a professional sender of strategic communication. This is not a claim concerning the concrete and specific situation of any empirical sender but a claim concerning the position of sender as such. This position seems to imply an "optic" or way of seeing and thinking that tends to make the sender ethically blind.

An objectification of the receiver is an almost inevitable consequence of communication planning, but it can be avoided (cf. Dervin \& Frenette in Rice \& Atkin, 2001). However, this is not an insight that necessarily comes naturally or intuitively to a sender. On the contrary, to be ethically competent as a sender is to understand this situation and to be able to put oneself in the place of the receiver by following the Golden Rule. To act as an ethical subject, the sender ought to reflect upon the fact that he or she is in the dominant position and is exercising power over the receiver. Therefore, the sender has a responsibility for the way he or she treats the receiver. So, a sender has a moral obligation to respect the receiver's right of self-determination. If the sender argues fairly, the receiver is responsible for his or her approval of a claim and for the consequences that might ensue from it. That is both an ethical and a democratic ideal. That is why senders ought to acquire ethical sensibility and ethical competence in their education, but a sense of ethics must also be "institutionalized" into the sender's organisation:

Ethical concerns must be regarded as on a par with economic and pragmatic concerns in decision making [...]. Ethical rules, principles, and codes can serve as important functions as guides to ethical communication in organizations. But rules, principles, and codes are 
not enough. Corporate culture and organizational policy are powerful forces that can mold the spirit of an organization, but they are no substitute for the character of individual employees (Johannesen et al., 2008, p.159).

My intention is not to exclude the receiver from ethical responsibility, to the contrary. The desirable thing, of course, is for the sender to communicate in such a way that the receiver can be responsible for giving his or her approval of the sender's message. And then, in principle, it is unimportant what this message is about. One could say that a receiver always has a responsibility not to let himself or herself be fooled or deceived by behaving in a stupid or naive way. There is no cure for stupidity. The purpose of an ethic of strategic communication is not to defend or to absolve the receiver's foolishness, ignorance or intellectual laziness. The typical situation in strategic communication often implies some degree of resistance in the receiver, which has to be overcome. Receivers are often "obstinate" and protect themselves against unpleasant and disconfirming messages - for example, messages that create cognitive dissonance (cf. Rogers, 1995; Festinger, 1957). Effective communication is both necessary and legitimate and does not exclude fairness in any way. It is ethically legitimate to try to influence others if it is done in a fair way.

Unequal access to various media and unequal economic and communicative resources are problems of a political nature. They are not ethical problems. Of course, it is a democratic problem that not everyone has the same possibility of influencing others. But this fact should not be confused with an ethical problem.

\section{Summary}

My contribution to an ethic of strategic mass communication is centred on the means of persuasion used in strategic communication, which is a crossover problem in the media and communication profession. The ethic examines the relationship between ends and means; and, more specifically, it examines whether a sender lets the end justify the persuasive means by deceiving the receiver. The basis of this ethic is the norm of fairness based on general humanistic values, especially the receiver's dignity and right to self-determination. This norm is not possible to define positively but only as any mode of persuasion that is not unfair. Therefore, the norm cannot be defined as a list of specific positive traits. Instead, the norm of fairness must be approached negatively, that is, via typical ways of being unfair.

The norm of fairness is difficult to operationalize: Whether or not some methods of persuasion have a misleading effect on the receiver must be based on a context-sensitive judgement, i.e., based on the total context of argumentation in which, for instance, a simplification is included. And, moreover, on the communication situation of which the media product is a part. Such a judgement demands an ethical competence that must be learned. A sender of strategic communication is always exercising power in an 
asymmetrical relationship. Therefore, the sender ought not to abuse this power but ought to respect the receiver's dignity and right of self-determination.

\section{References}

Bauman, Z. (1988). Freedom. Buckingham: Open University Press.

Bauman, Z. (1993). Postmodern Ethics. Oxford: Blackwell.

Botan, C. (1997). Ethics in strategic communication campaigns: The case for a new approach to public relations. The Journal of Business Communication, 34(2, 1),188-202.

Brurås, S. (2002). Etikk for journalister. Bergen: Fakbookforlaget.

Buber, M. (1965). Between man and man. London: Macmillan

Cave, P. (2009). Humanism. Oxford: Oneworld.

Cheney, G. et al. (Eds.) (2011). The Handbook of communication ethics.New York:Routledge.

Christians, C. \& Traber, M. (Eds.) (1997).Communication ethics and universal values. Thousand Oaks: Sage Publications.

Christians, C. (2015). Media ethics: Cases and moral reasoning (9th ed.). New York: Routledge.

Drumwright, M. (Ed.) (2013). Ethical issues in communication professions. London: Routledge.

Femø, M. \& Koch, C. (2009). Politisk kommunikation. In J. Helder,T. Bredenlöw \& J. L. Nørgaard (Eds.),

Kommunikationsteori (pp. 365-414). Copenhagen: Hans Reitzels Forlag.

Festinger, L. (1957). A theory of cognitive dissonance. Stanford: Stanford University Press.

Foucault, M. (1980). Power/knowledge: Selected interviews \& other writings 1972-1977. New York: Random House.

Foucault, M. (1994). Ethics: Essential works of Foucault Volume 1. London: Penguin Books.

Gordon, A. D. \& Kittross, J., M. (Eds.) (1999).Controversies in media ethics. New York: Longman.

Guttman, N. \& Thompson, T. (2011): Ethics in health communication. In G. Cheney, S. May \& D. Munshi

(Eds.), The handbook of communication ethics (pp. 293-308). London and New York: Routledge.

Habermas, J. (1991). Moral consciousness and communicative action. Cambridge, Massachusetts: The MIT

Press.

Habermas, J. (1993). Justification and application: Remarks on discourse ethics. Massachusetts: Polity Press. Hall, Roland (1959). Excluders. In Caton, London.

Hanson, R. (2017). Mass communication. London: Sage Publications.

Jowett, G. S. \& O'Donnell, V. (2006). Propaganda and persuasion. London: Sage Publications.

Johannesen, R. L., Valde, S. K. \& Whedbee, K. E. (2008). Ethics in human communication. Illinois: Waveland Press.

Jønch-Clausen, H. \& Lyngbye, F. (2007). Hvad er fairness? Journalistica, 5, 91-107.

Jørgensen, C. \& Onsberg, M. (1999). Praktisk argumentation. Copenhagen: Teknisk Forlag.

Jørgensen, C. (2007). The relevance of intention in argument evaluation. Argumentation, 21, 165-174. DOI

$10.1007 / \mathrm{s}$ 10503- 007-9044-0

Kahneman, D. (2011). Thinking fast and slow. New York: Brockman.

Laclau, E. \& Mouffe, C. (2002). Det radikale demokrati: Diskursteorienspolitiske perspektiv. Copenhagen:

Roskilde Universitetsforlag.

Lakoff, G. (2004). Don't think of an elephant: Know your values and frame the debate. White River Junction:

Chelsea Green Publishing Company.

Lakoff, G. (2008). The political mind. New York: Penguin.

Levinas, E. (1991). Totality and infinity. Dordrecht: Kluwer. 
L'Etang, J. (2011). Public relations and marketing: Ethical issues and professional practice in society. In G.

Cheney et al. (Eds.), The handbook of communication ethics. (pp. 221-240). London and New York: Routledge.

Merkelsen, H. (Ed.) (2010). Håndbog i strategisk public relations. Copenhagen: Samfundslitteratur.

Mikkelsen, J. F. (2002). Formidlingsetik. Copenhagen: Roskilde Universitetsforlag.

Mikkelsen, J. F. (2007). Etik og moral. Copenhagen: Tiderne Skifter.

Mumby, D. (2011): Power and ethics. In G. Cheney et Al. (Eds.) The handbook of communication ethics (pp.

84-98). London: Routledge.

Norman, R. (2004). On humanism. London: Routledge.

Rice, R. S. \& Atkin, C. K (Eds.) (2001). Public communication campaigns. California: Sage Publications.

Ricoeur P. (1994). Oneself as another. Chicago: The University of Chicago Press.

Rogers, E. (1995). Diffusion of innovations. New York: The Free Press.

Rorty, R. (1989). Contingency, irony and solidarity. Cambridge: Cambridge University Press.

Rorty, R. (1999). Philosophy and social hope. New York: Penguin.

Toulmin, S. (1974). The uses of argument. Cambridge: Cambridge University Press.

Sepstrup, P. \& Fruensgaard, P. (2010). Tilrettelaggelse af information: Kommunikations- og

kampagneplanlagning. Copenhagen: Academica.

Taylor, C. (1989). The sources of the self. Cambridge: Harvard University Press.

Vatimo, G. (2004). Nihilism and emancipation: Ethics, politics, law. New York: Columbia University Press.

Vetlesen, A. J. (2007). Hva er etikk? Oslo: Universitetsforlaget.

Ward, P. (2005). Documentary: The margins of reality. London: Wallflower.

Windahl, S. \& Signitzer, B. (1995). Using communication theory: An Introduction to strategic communication. London: Sage Publications.

Jan Foght Mikkelsen

Associate Professor

Department for Communication and Humanistic Science

Roskilde University

jfm@ruc.dk 